\title{
Measurement of free shrinkage at the tissue level using an optical microscope with an immersion objective: results obtained for Douglas fir (Pseudotsuga menziesii) and spruce (Picea abies)
}

\author{
Patrick PERRÉ*, Françoise HUBER \\ LERMaB (Integrated Research Unit of Wood Science), UMR 1093 INRA/ENGREF/University H. Poincaré Nancy I, ENGREF, \\ 14, rue Girardet, 54042 Nancy, France
}

(Received 17 May 2006; accepted 28 September 2006)

\begin{abstract}
Shrinkage at the tissue level has been evaluated satisfactorily using relatively simple equipment, comprising an optical microscope equipped with reflected light, a standard objective, a water immersion objective of same magnification and a digital camera connected to a computer. Shrinkage is calculated from pairs of images taken at the same magnification, one collected during immersion in water and the other in air-dry state. A novel software program has been developed to determine shrinkage based on a closed chain of reference points chosen from the anatomical markers at the external part of the zone of interest. Measurements were performed on earlywood, latewood and compression wood zones from two softwood species (Douglas fir and spruce), isolated from the rest of the annual ring with the aid of a diamond wire saw. As main results, reference should be made to the low degree of shrinkage and high anisotropy factor of earlywood, the marked and practically isotropic shrinkage in latewood and the low shrinkage (with respect to cell wall thickness) and inverse anisotropy ratio in compression wood.
\end{abstract}

image analysis / microscope / shrinkage / softwood / tissue

Résumé - Mesure du retrait libre à l'échelle des tissus à l'aide d'un microscope optique muni d'un objectif à immersion : résultats obtenus chez le Douglas (Pseudotsuga menziesii) et l'épicéa (Picea abies). Le retrait a été évalué de façon satisfaisante à l'échelle tissulaire en utilisant un équipement relativement simple : un microscope optique, un objectif standard, un objectif à immersion de même grossissement et une caméra digitale reliée à un ordinateur personnel. Le retrait est déterminé par comparaison de deux images : l'une obtenue en immersion dans l'eau et l'autre à l'état sec à l'air. Un logiciel nouveau a été développé pour extraire le retrait à partir d'une chaîne fermée de points situés à la périphérie de la zone d'intérêt. Les mesures ont été effectuées sur des zones de bois initial, de bois de compression et de bois final de deux espèces (Douglas et sapin). Ces zones sont isolées du reste de l'accroissement initial à l'aide d'une scie à fil diamanté. Les principaux résultats montrent le faible niveau de retrait et la forte anisotropie du bois initial, le fort retrait, presque isotrope, du bois final et la faible valeur, en rapport à sa densité, avec une anisotropie inversée, du bois de compression.

analyse d'image / microscope / résineux / retrait / tissu

\section{INTRODUCTION}

Shrinkage is a phenomenon which is detrimental to the utilisation of wood. Its macroscopic expression is the result of interactions at several spatial levels of the shrinkage of components making up this material (multilayered cell wall, cell shape, ray cells, earlywood-latewood alternation...). This complexity hinders the scientists in their efforts to study the parameters involved in dimensional variations, so that shrinkage, and particularly its transverse anisotropy (radial/tangential) has been the subject of considerable attention since several decades $[2,5,6,11,12,20,23,24]$.

In 1989, Mariaux [14] suggested that the anatomical pattern was of importance, as it is made up of different cell types which all play specific roles in shrinkage. For example, he observed that the transverse anisotropy of tissues depended on mean cell elongation, but that shrinkage was not isotropic for

\footnotetext{
* Corresponding author: perre@ nancy-engref.inra.fr
}

"isotropic" cells (same mean diameter in both the radial and tangential directions).

In spruce wood, Mazet and Nepveu [15] saw a relation between shrinkage and basic density but this relation did not apply in the case of compression wood. This finding is indeed well-established: in annual ring with reaction wood, latewood and reaction wood undergo radial shrinkage which is much less marked than that of the latewood part of normal wood [7]. Later, Watanabe and Norimoto [22] observed that numerous resinous species displayed less radial and tangential shrinkage in compression wood than in normal wood.

In softwood, tangential shrinkage of earlywood is very often greater than radial shrinkage [4]. By contrast, this author reports that the tangential shrinkage is less marked than radial shrinkage in reaction wood from the same species.

Thus numerous authors have studied the shrinkage of the different tissues making up wood, but these tissues nonetheless remained linked together. Although numerous works exist to 
propose explanations or modelling of the transverse anisotropy of wood, the measurement of free shrinkage on very small samples, at the tissue level, remains scarce. Except some recent studies performed on softwood [22-24] and on oak wood $[1,21]$ only works published some decades ago proposed this kind of measurement $[3,5,6,14,20]$.

Nevertheless, if we are to gain a clearer understanding of the effects of species and growth conditions (silviculture, climate, etc.) on shrinkage, we need to determine how each of these component tissues shrinks freely and separately [1]. Indeed, because of differences in anatomical structure (cell shape, cell wall thickness, mean microfibril angle, direction of cells, etc.), their reaction to a change in moisture content may be markedly contrasted. And in a material produced by a plant, determining local shrinkage is only possible if the different tissues can be isolated before this shrinkage is measured. This paper proposes a new method to measure free shrinkage in very small areas. To achieve this, the portion of tissue concerned is isolated from the rest of the material (in terms of kinematics), an image of this zone (R-T plane) is grabbed at a certain water content (generally at saturation) and then at a different water content (in this case, in an air-dry state). The difference between the two states makes it possible to determine the relative shrinkage of different tissues, or the anisotropy factor between two directions included in the image. To determine this shrinkage accurately in these isolated zones, new functions have been added to the software MeshPore previously developed in our team [18]. Shrinkage is thus calculated from contour integrals on closed chains of reference points selected in the external part of the selected zone.

During this study, the wood zones thus actually behaved as separate tissues. Moreover, during the implementation of the experimental protocol, the samples did not undergo any treatment except for the cautious polishing necessary to satisfactorily mark the cell walls. This possibility to measure shrinkage on intact wood specimens, in spite of their very small size, the good control of the saturated state and the mathematical approach used to measure the shrinkage values are certainly among the key features of our method, compared to other authors $[5,14,20]$.

\section{MATERIAL AND METHODS}

\subsection{Material}

The studies were performed on wood from a Douglas fir (Pseudotsuga menziesii) tree and a spruce (Picea abies) tree, the samples being collected at breast height. We selected annual rings which were broad enough to obtain homogeneous sub-units in spite of the matter loss due to cutting (the ring width was approximately $7 \mathrm{~mm}$ for the two rings of Douglas fir and $3.5 \mathrm{~mm}$ in width for the cambial age of 19 years, and $8 \mathrm{~mm}$ for the cambial age of 24 years, in spruce). These two trees came from a forest near Nancy, belonging to ENGREF.

The disk of Douglas fir tree comprised 25 rings. The present study focused on a 14-year-old ring and a 17-year-old ring. Only the 14year-old ring contained compression wood. Two samples were collected from this ring, one on the reaction wood side and the other on the opposite side.
We collected four samples from the 19-year-old ring of the spruce tree, two from the reaction wood side and two from the opposite side. However, two samples were collected from the normal wood (lateral side) only in the 24-year-old ring. Indeed, on the reaction wood side, the ring was narrow (like all the others, except for "ring 19"). In "ring 24 ", only one sample was taken from the wood opposite the reaction wood, for the same reasons.

\subsection{Preparation of samples}

Small samples of about $2 \mathrm{~cm}^{3}$ were obtained in the green state by sawing and then splitting along the grain of the wood. Their transversal surface was polished as perpendicularly as possible to the wood grain, using disks covered with aluminium oxide abrasives of decreasing roughness. Four series of disks were used, of 320, 600, 2000 and 4000 grains per inch (the finest corresponding to grains of about $6 \mu \mathrm{m})$. Self-adhesive sanding disks were fixed on glass plates, which in turn were attached to light alloy plates. These easily interchangeable plates were mounted on a horizontal rotary sanding machine. In order to prevent drying of the green wood, polishing was performed under water in the present study devoted to shrinkage. Polishing was pursued until the cell walls could be seen clearly with an optical microscope in polarised reflected light.

The different tissues were identified within the zone to be studied. Homogeneous sub-units of tissues of about $0.7 \mathrm{~mm} \times 0.7 \mathrm{~mm}$, radial/tangential dimensions, were partially isolated from the wood block using a diamond wire microsaw. They contain a single tissue, on which dimensional variations were measured. The key feature of the wire saw is a high tensile core wire, $0.3 \mathrm{~mm}$ in diameter, in which diamonds, about $60 \mu \mathrm{m}$ in size, are impregnated. The total wire length is $10 \mathrm{~m}$, winding and unwinding on two bobbins. A thread system ensured that the wire remained perfectly vertical as it moved. Cutting was performed at a constant load (simply obtained by gravity effect), thus ensuring very little stress and no heating. In addition, during our study protocol, the wire was submerged in water, thus causing a water film which prevented any drying of the sample. The zones were sawn longitudinally over a length of about $4 \mathrm{~mm}$ which, given the cross-section of sub-units, was entirely sufficient to insure free shrinkage on the upper surface. All zones thus remained part of the initial block, facilitating referencing and handling (Fig. 1).

The latewood part of spruce has a very small radial extension [10]. In practice, this zone does not exceed 15 cells, hence smaller than the width of a sub-unit. Latewood was thus isolated tangentially by hand under a binocular microscope. Four mm deep splits were made in the tangential-longitudinal plane, so that the tissue remained fixed to its own substrate while allowing free shrinkage at the level of the cells measured on its transversal surface. This precaution was particularly necessary to avoid tangential coupling in a zone where density varied considerably along the radial direction.

\subsection{Obtaining the images}

The base block was fixed in modelling clay. This mechanically plastic substrate made it possible to place the surface to be observed parallel to the focal plane of the objectives, using an alignment system. Images of sub-units were collected using an optical microscopy set in reflected light. A pair of polarising filters, placed on the incident and reflected lights respectively, eliminated any reflection. This 

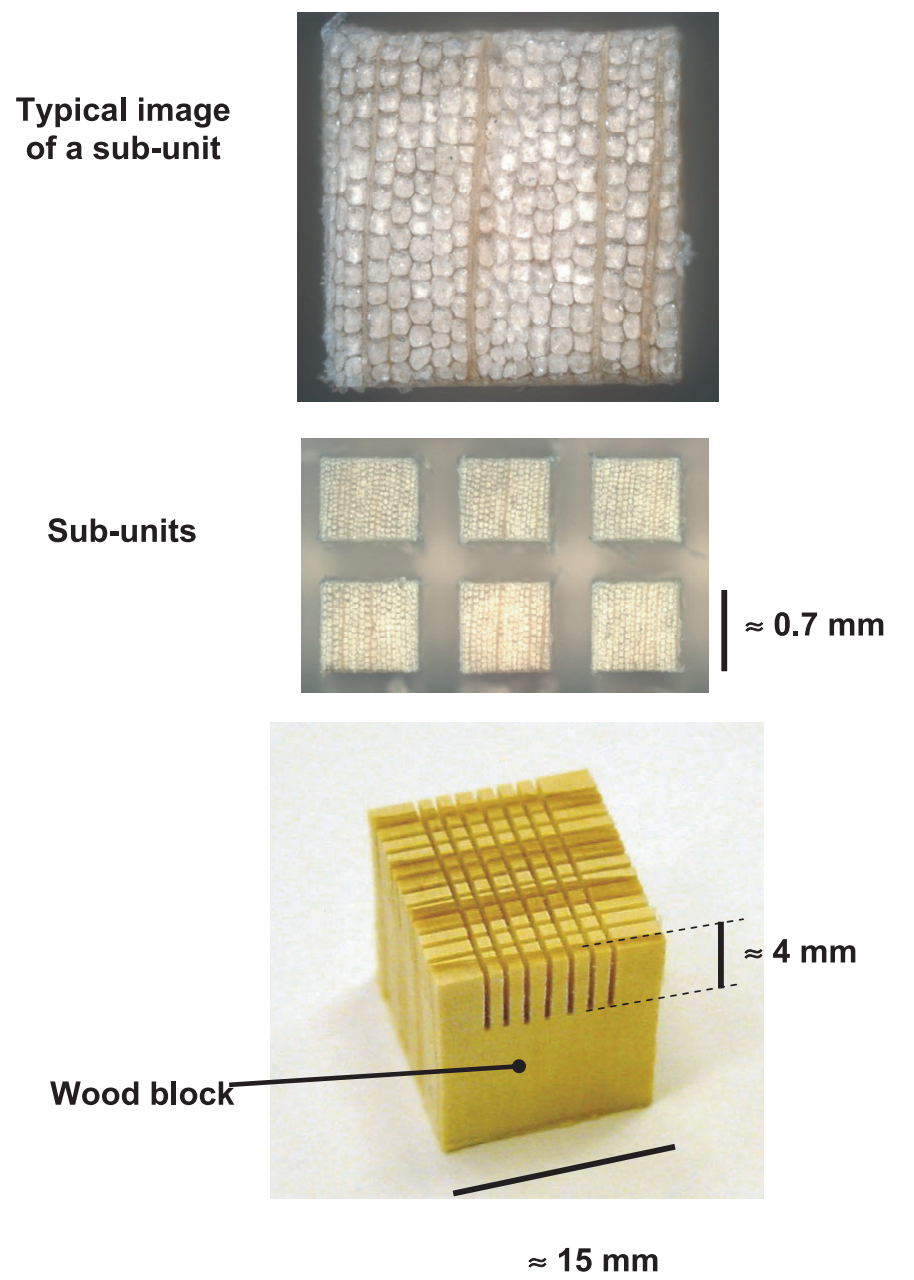

Figure 1. Separation of sample in sub-units using a diamond wire micro-saw. The upper face of the sample is carefully polished before sawing to ensure a good quality of the microscopic observation.

assembly was equipped with a digital camera managed by an imaging software system (Coolsnap).

First of all, images were collected on saturated samples, using a water immersion objective (Fig. 2). Magnification $\times 10$ was chosen in order to visualise each sub-unit in its entirety. This initial image was taken with the sample completely soaked, thus preventing any shrinkage.

The wood sample (base block with all its sub-units) and its support (microscope slide and modelling clay) were then removed from the water and left for ten days under ambient conditions in the laboratory (approximately $20{ }^{\circ} \mathrm{C}$ and $50 \% \mathrm{RH}$ ). After that period, checks were made to ensure that the wood samples had practically attained their steady state, at around $9 \% \pm 1 \%$. Because the modelling clay partly penetrated the base of the block, this steady-state water content was not measured on the samples themselves, but on control samples. It should be noted that the sub-units, with very small sections, in fact reached their steady state within a much shorter period of time.

A second image was then collected in air-dry conditions using a standard objective of same magnification, from the same manufacturer (Fig. 2).
All the shrinkage values referred to in this article thus correspond to the difference in dimension between the saturated state and the airdry state $(9 \% \pm 1 \%)$. They are expressed as percentages.

\subsection{Shrinkage determination}

Shrinkage in each sub-unit was determined by comparing the two images obtained of this zone (Fig. 3). The mechanics of continuum media tells us that these two images are separated locally by translation, rotation and deformation. The latter, induced by shrinkage, is in this case the datum of interest. If two points on the reference configuration (saturated state) are called $\mathrm{A}_{0}$ and $\mathrm{A}$, and the position of these two material points identified on the generic configuration (airdry state) are called $\mathrm{M}_{0}$ and $\mathrm{M}$, the vector calculation rules allow us to write:

$$
\overrightarrow{\mathrm{OM}}=\overrightarrow{\mathrm{OA}}+\overrightarrow{\mathrm{AA}}_{0}+{\overrightarrow{\mathrm{A}_{0} \mathrm{M}_{0}}}_{+}+\overrightarrow{\mathrm{M}_{0} \mathrm{M}}
$$

If points $\mathrm{A}_{0}$ and $\mathrm{A}$ are sufficiently close, a first order development of their position in the deformed image enables vector $\overrightarrow{\mathrm{M}_{0} \mathrm{M}}$ to be represented as the product of the deformation gradient tensor $\overline{\overline{\mathrm{F}}}$ and vector $\overrightarrow{\mathrm{A}_{0} \mathrm{~A}}$

$$
\overrightarrow{\mathrm{M}_{0} \mathrm{M}}=\overline{\overline{\mathrm{F}}} \overrightarrow{\mathrm{A}_{0} \mathrm{~A}}
$$

Equation (2) is linear locally since $\overline{\bar{F}}$ depends on $A_{0}$ but not on $\overrightarrow{A_{0} A}$. In our application, we supposed that the deformation was constant over the entire image, i.e. that $\overline{\overline{\mathrm{F}}}$ does not depend on $\mathrm{A}_{0}$. The development of equation (2) is thus valid for all reference points on the image. In addition, we assumed that deformation remains small (hypothesis of small perturbations). Tensor $\overline{\overline{\mathrm{F}}}$ thus differs little from the identity tensor $\overline{\bar{I}}$. By breaking down their difference into a symmetric part $\overline{\bar{\varepsilon}}$ and an antisymmetric part $\overline{\bar{\Omega}}$, we simply find approximations of the deformation tensor and rotation tensor, respectively:

$$
\overline{\overline{\mathrm{F}}}-\overline{\overline{\mathrm{I}}}=\overline{\bar{\varepsilon}}+\overline{\bar{\Omega}}
$$

If $(\mathrm{a}, \mathrm{b})$ and $(x, y)$ are the coordinates of points $\mathrm{A}$ and $\mathrm{M}$, in the initial image and deformed image, respectively, a combination of equations (1) to (3) gives a relationship linking the coordinates of a reference point in the deformed image $\mathrm{M}$ as a function of the coordinates of the same point in the initial image $\mathrm{A}$ :

$$
\left|\begin{array}{l}
x \\
y
\end{array}=\right| \begin{aligned}
& \mathrm{a} \\
& \mathrm{b}
\end{aligned}+\left|\begin{array}{l}
x_{0}-\mathrm{a}_{0} \\
y_{0}-\mathrm{b}_{0}
\end{array}+\right| \begin{array}{ll}
\varepsilon_{11} & \varepsilon_{12} \\
\varepsilon_{12} & \varepsilon_{22}
\end{array}|\times| \begin{aligned}
& \mathrm{a}-\mathrm{a}_{0} \\
& \mathrm{~b}-\mathrm{b}_{0}
\end{aligned}+\left|\begin{array}{ll}
0 & \omega \\
-\omega & 0
\end{array}\right| \times \mid \begin{aligned}
& \mathrm{a}-\mathrm{a}_{0} \\
& \mathrm{~b}-\mathrm{b}_{0}
\end{aligned} .
$$

Because we supposed the deformation to be constant throughout the image, point $\mathrm{A}$ needs not necessarily be close to $\mathrm{A}_{0}$. By placing the latter at the point on the initial image at the origin of the coordinates system (if necessary, prolonging the image to that point virtually), equation (4) reduces to

$$
\left|\begin{array}{l}
x \\
y
\end{array}=\right| \begin{aligned}
& \mathrm{a} \\
& \mathrm{b}
\end{aligned}+\left|\begin{array}{l}
\mathrm{A} \\
\mathrm{B}
\end{array}+\right| \begin{aligned}
& \varepsilon_{11} \mathrm{a}+\left(\varepsilon_{12}+\omega\right) \mathrm{b} \\
& \varepsilon_{22} \mathrm{~b}+\left(\varepsilon_{12}-\omega\right) \mathrm{a}
\end{aligned} .
$$

On each pair of images, the deformation tensor $\overline{\bar{\varepsilon}}$ was determined using a series of reference points for which the position was known on both the reference configuration $\mathrm{A}_{\mathrm{i}}$ and the deformed configuration $\mathrm{M}_{\mathrm{i}}$. These points were chosen using anatomical marks. 


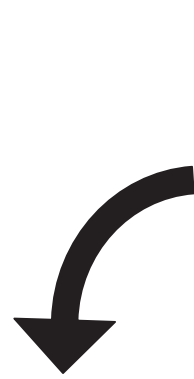

Observation of the soaked sample
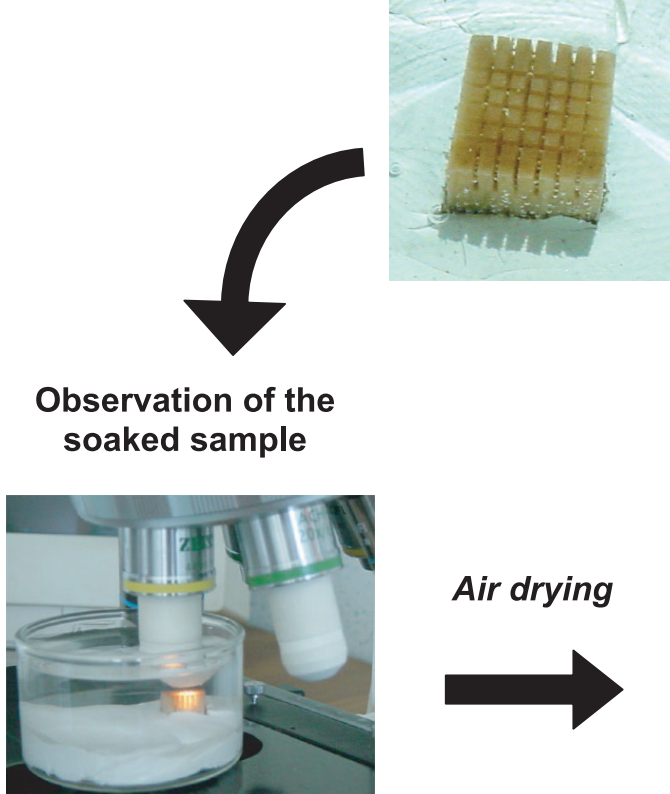

Polished sample with sub-units isolated using a diamond wire saw
Observation of the airdry sample

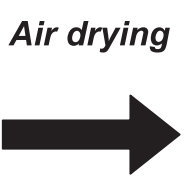

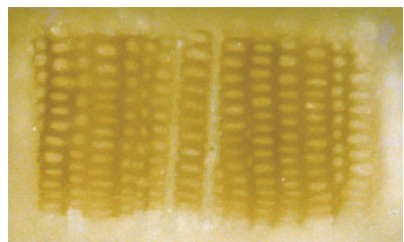
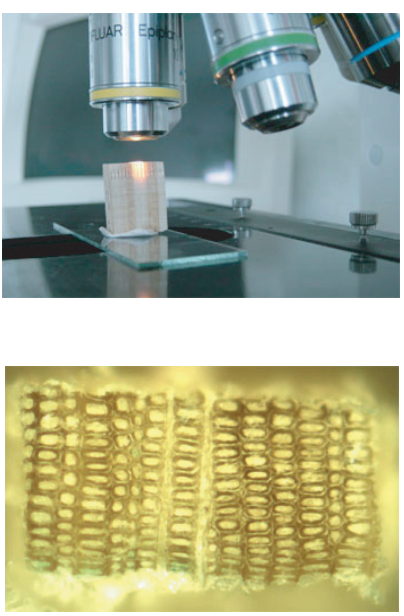

Figure 2. Summary of the experimental protocol: the sample, prepared as specified in Figure 1, are observed with an optical microscope in reflected light, at first with a water immersion objective and, after air-drying, with a standard objective (images used in this work contain 696 $\times 520$ pixels).

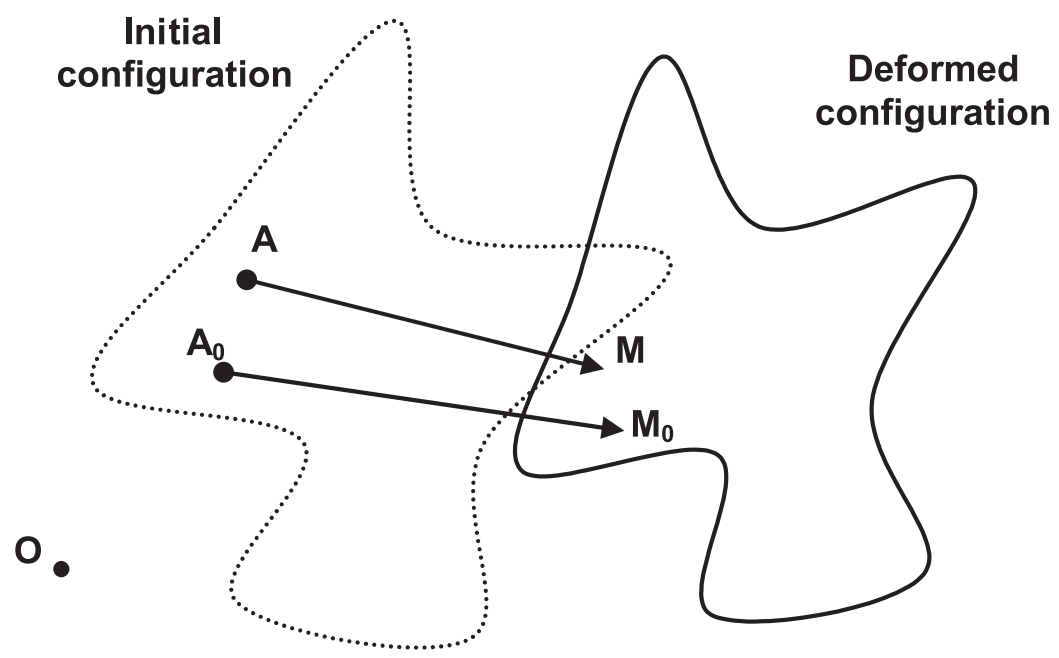

Figure 3. Notations used in the text to follow the materials points from the initial configuration (image of the saturated sample) to the deformed configuration (image of the air-dry sample). 
Depending on the image (tissue type and image quality), three types of anatomical marks were used:

- The triple point: the point at the intersection of three cells. This type of marker functions very satisfactorily with earlywood.

- Mid-segment: the point situated halfway between two triple points. This was the solution adopted when the image was of poor quality.

- The centre of cell lumens. This reference is precise for small cells or for the round lumens found in compression wood.

The software program MeshPore, developed in our team [18], was used to achieve this manual referencing on the images. In order to facilitate this tedious operation, several functionalities were implemented in MeshPore:

- simultaneous work on two images, with rapid passage from one to the other by clicking on a menu button,

- cloning of a chain of points and free translation of this duplicated chain.

The work on a pair of images started by plotting a chain of points on the initial image. To allow the data analysis as presented below, this chain must be closed. It is duplicated before moving on to the deformed image. By translating this duplicated chain, one of the reference points was placed at the correct position on the deformed image. It was then necessary to shift each point in the chain slightly to the new position. Rapid switching from one image to the other was extremely useful during this phase: it enables the clear detection of each anatomical reference point chosen on the initial image. During this procedure, several functions in the MeshPore software were of particular value:

- shifting of a point in the chain,

- addition of a point,

- removal of a point,

- zoom on problematic zones,

- translation of the zoomed zone, with automatic updating of the two chains of reference points, etc.

Indeed, some of the reference points chosen on the initial image were either difficult to detect or invisible on the deformed image. In some cases, it was therefore necessary to modify the reference points (shift, addition, removal) on the initial image before returning to the deformed image. Before the chains could be validated to calculate shrinkage, each reference point was checked rapidly thanks to simple switching from one image to the other (the two chains always being visible on the screen). An example of chains can be seen in Figure 4.

Two different methods were used to extract deformation values from each pair of chains. The first consisted in minimising the difference between the deformed position determined from the image and calculation of this position using equation (5), this difference $F$ being determined by the sum of the distances squared:

$$
\mathrm{F}\left(\mathrm{A}, \mathrm{B}, \varepsilon_{11}, \varepsilon_{22}, \varepsilon_{12}, \omega\right)=\sum_{\mathrm{i}=1}^{\mathrm{n}-1}\left[\left(x_{i}^{\mathrm{mes}}-x_{i}^{\mathrm{cal}}\right)^{2}+\left(y_{i}^{\mathrm{mes}}-y_{i}^{\mathrm{cal}}\right)^{2}\right]
$$

where:

$$
\mid \begin{aligned}
& x_{\mathrm{i}}^{\text {cal }}=\mathrm{a}_{\mathrm{i}}+\mathrm{A}+\varepsilon_{11} \mathrm{a}_{\mathrm{i}}+\left(\varepsilon_{12}+\omega\right) \mathrm{b}_{\mathrm{i}} \\
& y_{\mathrm{i}}^{\text {cal }}=\mathrm{b}_{\mathrm{i}}+\mathrm{B}+\varepsilon_{11} \mathrm{~b}_{\mathrm{i}}+\left(\varepsilon_{12}-\omega\right) \mathrm{a}_{\mathrm{i}}
\end{aligned} .
$$
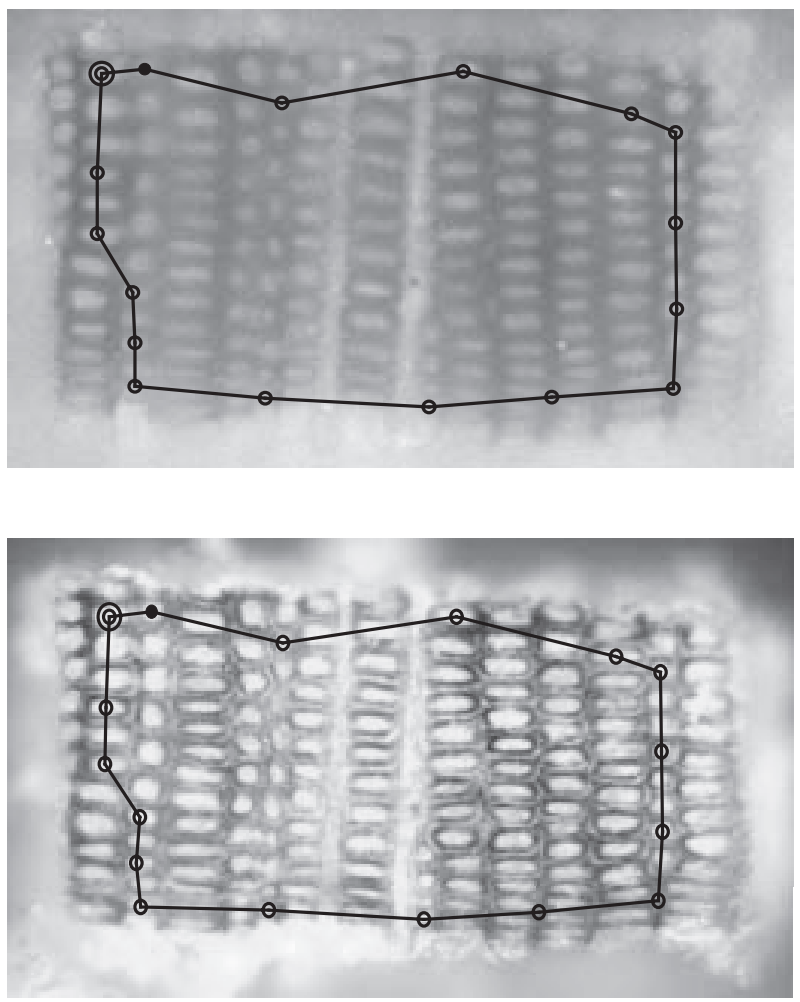

Figure 4. Example of two images (initial and deformed) and the corresponding chains of points plotted using the software MeshPore (Perré, [18]). This example corresponds to image 4 of spruce (latewood).

For a total number of points equal to $n$, the sum stops at $n$ - 1 because all chains are closed. Thus $\mathrm{F}$ is a function with six independent variables. At the minimum of the function, the partial derivative with respect to each of the variables has to be equal to zero. Thanks to the assumption of small perturbations, writing this condition generates a linear system of six equations with six unknowns (the six variables of function F). This system was solved by simply inverting the matrix. Of these unknowns, A and B, the translation of the origin, are of no importance, $\omega$ is a rotation which was always close to zero since the sub-units were fixed on a large base, and $\varepsilon_{12}$ is the shear strain which was also always close to zero because the sub-units were cut along the material directions of wood. Finally, $\varepsilon_{11}$ and $\varepsilon_{22}$ are the two parameters sought: they represent the shrinkage values in directions $x$ and $y$, respectively, and thus in directions $\mathrm{R}$ and $\mathrm{T}$ or $\mathrm{T}$ and $\mathrm{R}$, depending on the orientation of the sub-unit.

The second method is based on Stokes' theorem:

$$
\oint_{\mathrm{c}} \mathbf{A} \cdot \mathrm{d} \mathbf{r}=\iint_{\mathrm{S}}(\nabla \times \mathbf{A}) \cdot \mathrm{d} \mathbf{S}
$$

where $\mathrm{S}$ is an open surface limited by a closed curve $\mathrm{C}$.

Based on this theorem, simple formulae could be deduced when the surface is in a plane. In particular, the mean values for $\varepsilon_{11}$ and $\varepsilon_{22}$ on surface $S,\left\langle\varepsilon_{11}\right\rangle$ and $\left\langle\varepsilon_{22}\right\rangle$, are defined by

$$
\begin{aligned}
& \left\langle\varepsilon_{11}\right\rangle=\left\langle\frac{\partial \mathrm{u}}{\partial x}\right\rangle=\frac{1}{S} \iint_{S} \frac{\partial \mathrm{u}}{\partial x} \mathrm{~d} x \mathrm{~d} y=\frac{1}{S} \oint_{\mathrm{C}} \mathrm{u} \cdot \mathrm{d} y \\
& \left\langle\varepsilon_{22}\right\rangle=\left\langle\frac{\partial \mathrm{v}}{\partial y}\right\rangle=\frac{1}{S} \iint_{S} \frac{\partial \mathrm{v}}{\partial y} \mathrm{~d} x \mathrm{~d} y=-\frac{1}{S} \oint_{\mathrm{C}} \mathrm{v} \cdot \mathrm{d} x .
\end{aligned}
$$


The surface area $\mathrm{S}$ is obtained using a similar expression

$$
S=\oint_{\mathrm{C}} x \cdot \mathrm{d} y=-\oint_{\mathrm{C}} y \cdot \mathrm{d} x
$$

In equations (8) and (9), $\mathrm{u}$ and $\mathrm{v}$ are the point displacements along $x$ and $y$ axis, respectively. Using the notation adopted previously, these displacements are obtained as follows:

$$
\mid \begin{aligned}
& \mathrm{u}=x-\mathrm{a} \\
& \mathrm{v}=y-\mathrm{b}
\end{aligned}
$$

Shear strain and rotation values were calculated directly from their definition using the assumption of small perturbations:

$$
\left\langle\varepsilon_{12}\right\rangle=\frac{1}{2}\left\langle\frac{\partial \mathrm{u}}{\partial y}+\frac{\partial \mathrm{v}}{\partial x}\right\rangle \quad \text { and } \quad\langle\omega\rangle=\frac{1}{2}\left\langle\frac{\partial \mathrm{u}}{\partial \mathrm{y}}-\frac{\partial \mathrm{v}}{\partial x}\right\rangle .
$$

In our case, these continuous integrals along a closed contour were discretized along our closed discrete chains. For example, for the first term of the deformation tensor, we obtained

$$
\left\langle\varepsilon_{11}\right\rangle=\frac{1}{\mathrm{~S}} \sum_{i=1}^{n-1} \frac{\mathrm{u}_{i}+\mathrm{u}_{i+1}}{2}\left(\mathrm{~b}_{i+1}-\mathrm{b}_{i}\right)
$$

where

$$
S=\sum_{i=1}^{n-1} \frac{\mathrm{a}_{i}+\mathrm{a}_{i+1}}{2}\left(\mathrm{~b}_{i+1}-\mathrm{b}_{i}\right) .
$$

The two methods were implemented in MeshPore. They generally produced very similar results (the difference usually observed being less than $0.2 \%$, absolute shrinkage value). However, the second method, which weights each point by the length of adjacent segments, distributed the information more accurately throughout the image. It is thus the values generated using this second method which are depicted in the tables.

In order to test the accuracy of this method, we took images of a test pattern engraved on a glass slide under the same experimental protocol, the "initial" image being that of the test pattern in water with the immersion objective, and the "deformed" image being that of the test pattern taken using the standard objective. The "deformation" measured under these conditions on the pairs of images was less than $0.2 \%$. It should be noted that this value incorporated two sources of error: the possible difference in magnification between the two objectives and the accuracy inherent to marking the reference points on the images. Furthermore, the same degree of error was found by voluntarily modifying the detection of a reference point on one of the images, by a slightly exaggerated value: the difference in shrinkage observed after this modification was approximately $0.1 \%$.

\section{RESULTS}

In both species, opposite wood and lateral wood exhibited very similar results. For this reason, these two types of wood were grouped and referred to as "normal wood" in the following.

\subsection{Results obtained for Douglas fir}

All the results obtained on Douglas fir wood are summarised in Table I and Figure 5. Measurements were grouped according to the wood type:

- earlywood, compression wood and latewood on the compression wood side,

- earlywood and latewood on the normal wood side.

The values obtained were very similar in the two rings chosen and have thus been grouped in Table I. In addition, the standard deviations obtained in the groups thus constituted were very small, and similar to measurement uncertainties, except in latewood. Latewood does tend to exhibit a higher value of shrinkage, so that the standard deviation was logically larger, even if it remained very small in terms of relative value. Indeed, the standard deviation represented approximately $10 \%$ of the measured values in all wood types.

This very limited dispersion made it possible to reason in terms of mean values. Points representing these mean values are shown as plain markers on Figure 5 (all individual points are also indicated by open circles). In this figure, radial (R) shrinkage ( $y$-axis) was traced as a function of tangential (T) shrinkage ( $x$-axis). A logarithmic scale was chosen so the lines corresponding to isovalues of the anisotropy ratio could also be plotted on the same graph.

On this graph, the path of mean values from earlywood to latewood was clearly demonstrative.

On the normal wood side, earlywood is a zone of low shrinkage and marked anisotropy $(\mathrm{T}=2.84 \%$ and $\mathrm{R}=1.25 \%)$, while the tissue become practically isotropic in latewood, with large shrinkage values $(\mathrm{T}=8.14 \%$ and $\mathrm{R}=8.20 \%)$. Compared to published data, $[3,20]$, our values are smaller for earlywood, probably because our method is able to focus on the very first part of earlywood, and quite similar for latewood.

On the compression wood side, earlywood was practically in the same position as the earlywood of normal wood, although anisotropy was slightly less marked $(\mathrm{T}=2.97 \%$ and $\mathrm{R}=1.60 \%$ ). In the inner part of the ring, in the zone of compression wood, shrinkage remained small, despite a higher density (these small shrinkage values in the transversal plane are well explained by the high value of the mean microfibril angle in compression wood), but the anisotropy ratio was inversed $(\mathrm{T}=1.73 \%$ and $\mathrm{R}=2.93 \%)$. This can be seen in Figure 5 from the symmetrical positions of compression wood and normal wood with respect to the bisector (isotropy line). Finally, latewood moved to the position of latewood in normal wood, with slightly lower values $(\mathrm{T}=6.64 \%$ and $\mathrm{R}=8.02 \%$ ).

In conclusion, three types of wood could be distinguished from the measurements performed on these two Douglas fir rings: earlywood, compression wood and latewood (Fig. 6).

\subsection{Results obtained for spruce}

All the results obtained on spruce are summarised in Table II and Figure 7. Measurements were also grouped as a function of wood type. The same observations as for Douglas 
Table I. Complete data set collected on the Douglas fir disk (14 and 17 year-old annual rings, cambial age).

\begin{tabular}{|c|c|c|c|c|c|c|c|}
\hline Zone & Type of wood* & Image number & $\begin{array}{l}\text { Cambial } \\
\text { age }\end{array}$ & $\begin{array}{c}\text { Tangential } \\
\text { shrinkage }(\%)\end{array}$ & $\begin{array}{c}\text { Average } \\
\text { (standard deviation) }\end{array}$ & $\begin{array}{c}\text { Radial shrinkage } \\
(\%)\end{array}$ & $\begin{array}{c}\text { Average } \\
\text { (standard deviation) }\end{array}$ \\
\hline \multirow{19}{*}{ Compression wood } & \multirow{10}{*}{ EW } & 1 & 14 & 3.1 & \multirow{10}{*}{$\begin{array}{c}2.97 \\
(0.32)\end{array}$} & 1.45 & \multirow{10}{*}{$\begin{array}{c}1.60 \\
(0.19)\end{array}$} \\
\hline & & 2 & 14 & 2.7 & & 1.7 & \\
\hline & & 3 & 14 & 2.8 & & 1.5 & \\
\hline & & 4 & 14 & 2.5 & & 1.3 & \\
\hline & & 9 & 17 & 3.2 & & 1.6 & \\
\hline & & 10 & 17 & 2.5 & & 1.4 & \\
\hline & & 11 & 17 & 3.3 & & 1.8 & \\
\hline & & 12 & 17 & 3.2 & & 1.9 & \\
\hline & & 13 & 17 & 3.1 & & 1.6 & \\
\hline & & 14 & 17 & 3.3 & & 1.75 & \\
\hline & \multirow{4}{*}{$\mathrm{CW}$} & 5 & 14 & 1.4 & \multirow{4}{*}{$\begin{array}{c}1.73 \\
(0.28)\end{array}$} & 2.6 & \multirow{4}{*}{$\begin{array}{c}2.93 \\
(0.24)\end{array}$} \\
\hline & & 6 & 14 & 1.6 & & 3.1 & \\
\hline & & 7 & 14 & 1.9 & & 2.9 & \\
\hline & & 8 & 14 & 2.0 & & 3.1 & \\
\hline & \multirow{5}{*}{ LW } & 16 & 17 & 6.6 & \multirow{5}{*}{$\begin{array}{c}6.84 \\
(0.39)\end{array}$} & 6.7 & \multirow{5}{*}{$\begin{array}{c}7.02 \\
(0.68)\end{array}$} \\
\hline & & 17 & 17 & 6.7 & & 7.7 & \\
\hline & & 18 & 17 & 7.2 & & 6.6 & \\
\hline & & 19 & 17 & 7.3 & & 7.8 & \\
\hline & & 20 & 17 & 6.4 & & 6.3 & \\
\hline \multirow{19}{*}{$\begin{array}{l}\text { Normal or opposite } \\
\text { wood }\end{array}$} & \multirow{8}{*}{ EW } & 21 & 17 & 2.2 & \multirow{8}{*}{$\begin{array}{c}2.84 \\
(0.48)\end{array}$} & 1.2 & \multirow{8}{*}{$\begin{array}{c}1.25 \\
(0.19)\end{array}$} \\
\hline & & 22 & 17 & 3.6 & & 1.3 & \\
\hline & & 23 & 17 & 2.2 & & 1.0 & \\
\hline & & 24 & 17 & 3.1 & & 1.4 & \\
\hline & & 25 & 17 & 2.8 & & 1.0 & \\
\hline & & 32 & 14 & 2.8 & & 1.5 & \\
\hline & & 33 & 14 & 2.8 & & 1.2 & \\
\hline & & 34 & 14 & 3.2 & & 1.4 & \\
\hline & \multirow{11}{*}{ LW } & 27 & 17 & 6.6 & \multirow{11}{*}{$\begin{array}{c}8.14 \\
(0.80)\end{array}$} & 8.7 & \multirow{11}{*}{$\begin{array}{c}8.20 \\
(0.60)\end{array}$} \\
\hline & & 28 & 17 & 7.3 & & 8.6 & \\
\hline & & 29 & 17 & 7.9 & & 8.1 & \\
\hline & & 30 & 17 & 7.8 & & 7.9 & \\
\hline & & 31 & 17 & 7.7 & & 8.3 & \\
\hline & & 35 & 14 & 8.3 & & 7.2 & \\
\hline & & 36 & 14 & 9.5 & & 8.5 & \\
\hline & & 37 & 14 & 9.0 & & 7.3 & \\
\hline & & 38 & 14 & 8.5 & & 8.5 & \\
\hline & & 39 & 14 & 8.4 & & 7.9 & \\
\hline & & 40 & 14 & 8.5 & & 9.2 & \\
\hline
\end{tabular}

\footnotetext{
* See Figure 6.
}

fir remain valid regarding the degree of standard deviation. However, the rings chosen in this spruce cross-section reveal more complex results.

On normal wood, earlywood is a highly anisotropic zone with higher shrinkage values than those found in the same zone of Douglas fir ( $\mathrm{T}=5.42 \%$ and $\mathrm{R}=2.14 \%)$. This difference could be explained by the very low density of early- wood in Douglas fir. In spruce, latewood was separated into two zones, LW1 containing cells with thick walls conserving sustained radial extension, and LW2, the terminal zone of latewood, which corresponded to a sudden lignification, without expansion, of all dividing cells of the cambial zone. This demarcation corresponds to the so-called early-latewood and late-latewood subdivisions, as proposed in [17] using a 


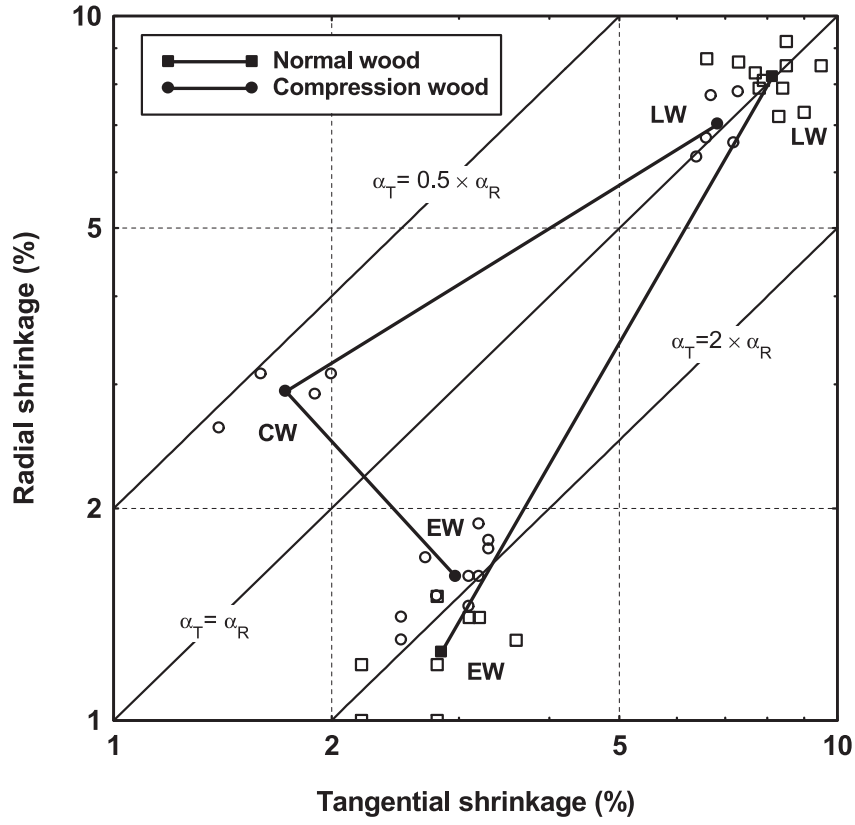

Figure 5. Radial shrinkage plotted versus tangential shrinkage for Douglas fir. Open marks represent individual measurements and plain marks average values per type of wood: earlywood (EW), compression wood $(\mathrm{CW})$ and latewood (LW), see Figure 6.

threshold value of 0.5 for the wall-lumen ratio. The first of these zones, LW1, exhibits marked shrinkage and was almost isotropic ( $\mathrm{T}=8.33 \%$ and $\mathrm{R}=5.87 \%$ ), while the anisotropy ratio is inversed in LW2 (the radial shrinkage is almost double the tangential shrinkage: $\mathrm{T}=4.35 \%$ and $\mathrm{R}=7.80 \%$ ).

On the compression wood side, earlywood differs considerably from earlywood of normal wood, with shrinkage closer to transverse isotropy ( $\mathrm{T}=3.30 \%$ and $\mathrm{R}=2.27 \%$ ). In the inner part of the ring, it was possible to distinguish two zones of compression wood, CW1, with low density, similar to earlywood $(\mathrm{T}=2.87 \%$ and $\mathrm{R}=1.90 \%)$ and $\mathrm{CW} 2$, a denser zone similar to latewood ( $\mathrm{T}=2.73 \%$ and $\mathrm{R}=2.07 \%$ ). It is surprising to observe that although these two zones differed from an anatomical point of view (Fig. 8) the shrinkage values are very similar (Fig. 7). A compensation effect between an increase in cell wall thickness and an increase in the mean microfibril angle might explain this result. Finally, the latewood is also somewhat surprising in that low shrinkage values are observed when compared with normal wood $(\mathrm{T}=2.33 \%$ and $\mathrm{R}=5.40 \%$ ). It thus appears that in this ring, the expression of reaction wood was prolonged into latewood.

In conclusion, seven types of wood could be distinguished from the measurements performed on these two spruce rings (Fig. 8).

- On the normal wood side: earlywood, latewood and terminal latewood (sudden lignification of dividing cambial cells).

- On the compression wood side: earlywood, low-density compression wood, high-density compression wood and latewood.
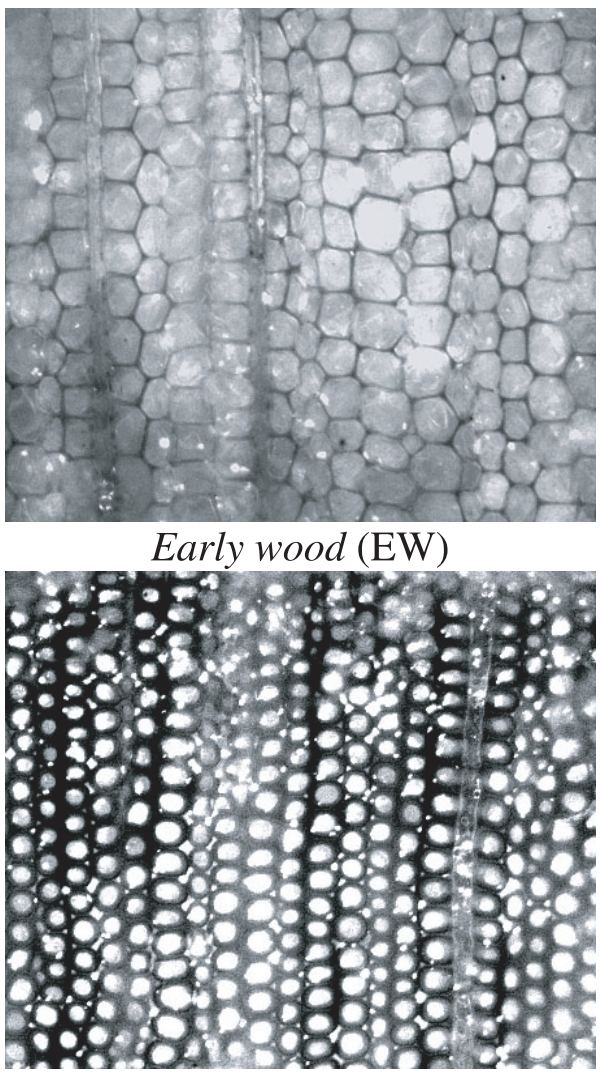
Compression wood (CW)

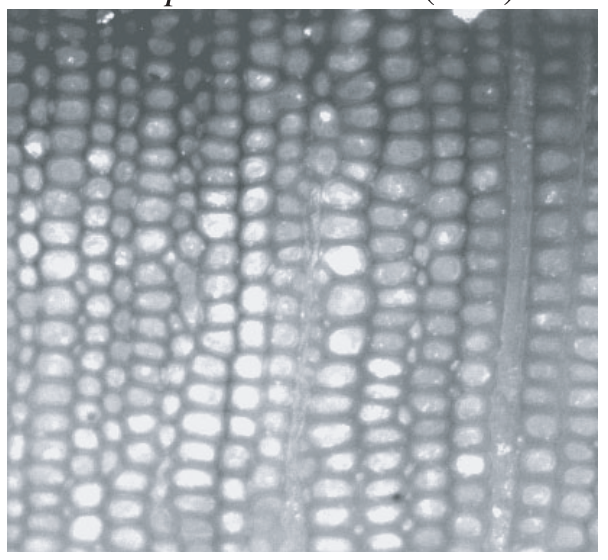

Late wood (LW)

Figure 6. The three types of wood distinguished from shrinkage results on Douglas fir.

\subsection{Discussion}

The difference observed between our measurements on the compression wood side in Douglas fir and spruce probably does not arise from a fundamental difference between these two species, but more likely from the much stronger expression of compression wood in the selected spruce ring. Indeed, it appears that this entire ring exhibited the characteristics of compression wood, both in terms of the shrinkage values measured and its anatomical characteristics. For example, 
Table II. Complete data set collected on the spruce disk (19 and 24 year-old annual rings, cambial age).

\begin{tabular}{|c|c|c|c|c|c|c|c|}
\hline Zone & Type of wood* & Image number & Cambial age & $\begin{array}{c}\text { Tangential } \\
\text { shrinkage (\%) }\end{array}$ & $\begin{array}{c}\text { Average } \\
\text { (standard deviation) }\end{array}$ & $\begin{array}{c}\text { Radial shrinkage } \\
(\%)\end{array}$ & $\begin{array}{c}\text { Average } \\
\text { (standard deviation) }\end{array}$ \\
\hline \multirow{12}{*}{ Compression wood } & \multirow{3}{*}{ EW } & 1 & 19 & 3.0 & \multirow{3}{*}{$\begin{array}{c}3.30 \\
(0.26)\end{array}$} & 2.0 & \multirow{3}{*}{$\begin{array}{c}2.27 \\
(0.46)\end{array}$} \\
\hline & & 2 & 19 & 3.5 & & 2.8 & \\
\hline & & 3 & 19 & 3.4 & & 2.0 & \\
\hline & \multirow{3}{*}{ CW1 } & 7 & 19 & 2.6 & \multirow{3}{*}{$\begin{array}{c}2.87 \\
(0.38)\end{array}$} & 2.1 & \multirow{3}{*}{$\begin{array}{c}1.90 \\
(0.20)\end{array}$} \\
\hline & & 8 & 19 & 3.3 & & 1.9 & \\
\hline & & 9 & 19 & 2.7 & & 1.7 & \\
\hline & \multirow{3}{*}{ CW2 } & 10 & 19 & 2.8 & \multirow{3}{*}{$\begin{array}{c}2.73 \\
(0.21)\end{array}$} & 2.3 & \multirow{3}{*}{$\begin{array}{c}2.07 \\
(0.25)\end{array}$} \\
\hline & & 11 & 19 & 2.9 & & 2.1 & \\
\hline & & 12 & 19 & 2.5 & & 1.8 & \\
\hline & \multirow{3}{*}{ LW } & 4 & 19 & 2.1 & \multirow{3}{*}{$\begin{array}{c}2.33 \\
(0.21)\end{array}$} & 5.3 & \multirow{3}{*}{$\begin{array}{c}5.40 \\
(0.10)\end{array}$} \\
\hline & & 5 & 19 & 2.4 & & 5.4 & \\
\hline & & 6 & 19 & 2.5 & & 5.5 & \\
\hline \multirow{10}{*}{$\begin{array}{l}\text { Normal or opposite } \\
\text { wood }\end{array}$} & \multirow{5}{*}{ EW } & 13 & 19 & 6.4 & \multirow{5}{*}{$\begin{array}{c}5.42 \\
(0.55)\end{array}$} & 2.1 & \multirow{5}{*}{$\begin{array}{c}2.14 \\
(0.18)\end{array}$} \\
\hline & & 14 & 19 & 5.2 & & 2.2 & \\
\hline & & 15 & 24 & 5.1 & & 1.9 & \\
\hline & & 16 & 24 & 5.2 & & 2.1 & \\
\hline & & 17 & 24 & 5.2 & & 2.4 & \\
\hline & \multirow{3}{*}{ LW1 } & 20 & 24 & 9.9 & \multirow{3}{*}{$\begin{array}{c}8.33 \\
(1.43)\end{array}$} & 6.5 & \multirow{3}{*}{$\begin{array}{c}5.87 \\
(0.57)\end{array}$} \\
\hline & & 21 & 24 & 8.0 & & 5.4 & \\
\hline & & 22 & 24 & 7.1 & & 5.7 & \\
\hline & \multirow{2}{*}{ LW2 } & 18 & 24 & 4.4 & \multirow{2}{*}{$\begin{array}{c}4.35 \\
(0.07)\end{array}$} & 8.2 & \multirow{2}{*}{$\begin{array}{c}7.80 \\
(0.57)\end{array}$} \\
\hline & & 19 & 24 & 4.3 & & 7.4 & \\
\hline
\end{tabular}

${ }^{*}$ See Figure 8.

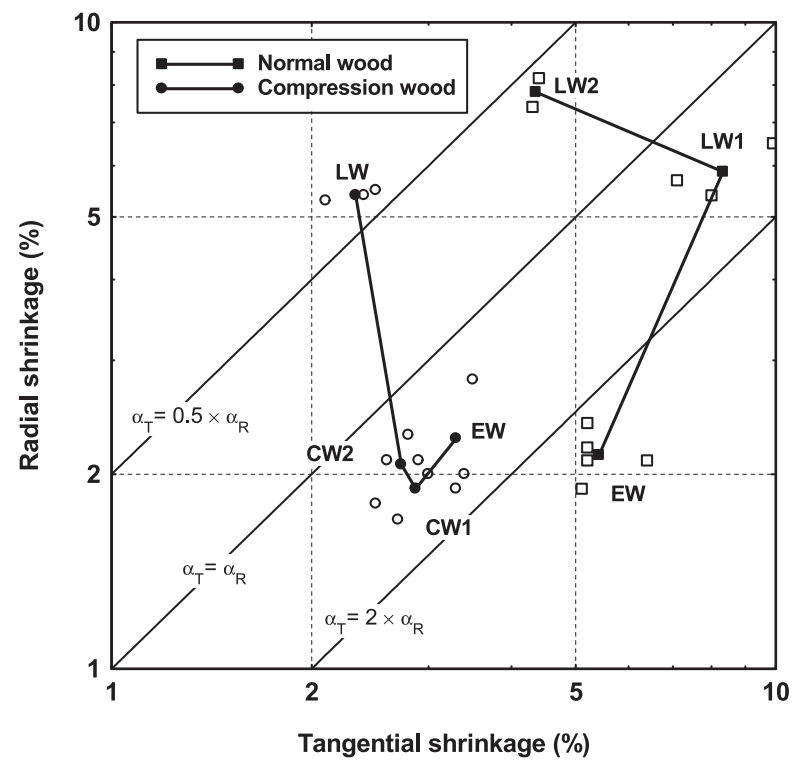

Figure 7. Radial shrinkage plotted versus tangential shrinkage for spruce. Open marks represent individual measurements and plain marks average values per type of wood: earlywood (EW), compression wood (CW1 and CW2) and latewood (LW1 and LW2), see Figure 8. the earlywood already exhibits round cells with intercellular spaces between tracheids (Fig. 8).

The trend for the softwood tissues to be become isotropic in latewood confirms the results obtained in the rare works devoted to shrinkage measurement of softwood tissues $[3,5$, $16,20,23,24]$. However, to our knowledge, this is the first time that an important inverse anisotropy factor was found in latewood ( $\mathrm{T}=4.35 \%$ and $\mathrm{R}=7.80 \%$ ). This is certainly due to the ability of our method to accurately determine shrinkage on samples comprising only a few cells in radial direction. Finally, one has to keep in mind that understanding and predicting the shrinkage anisotropy of wood tissues is not straightforward. Although the cellular shape is well-known to be the key factor to explain the anisotropy factor of cellular materials concerning the elasticity behaviour $[8,9]$, the explanation fails for shrinkage. It is acknowledged that the pore volume remains almost constant during shrinkage [13]. Consequently, the volumetric shrinkage increases with density. But two questions remain open: (i) Why does the pore volume remain constant? (ii) Why the anisotropic factor tends to decrease when density increases? It seems that the combined effects of the cellular shape and the local anisotropy of cell walls have to be involved, i.e. by applying homogenisation on actual pore structures [19], to explain the anisotropy factor at the tissue 


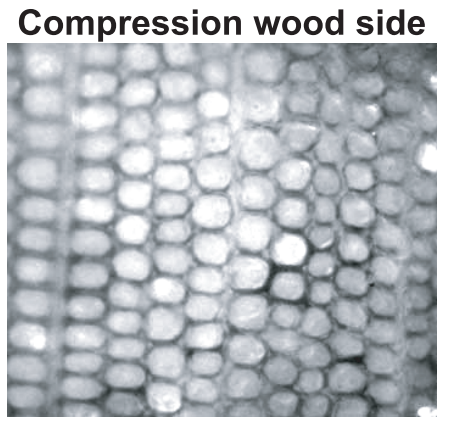

Early wood (EW)

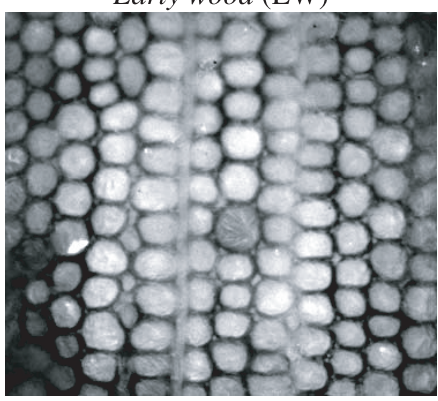

Compression wood near EW (CW1)

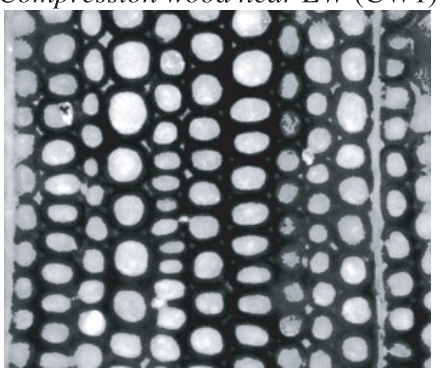

Compression wood near $L W(\mathrm{CW} 2)$

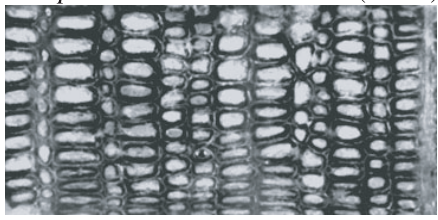

Late wood (LW)

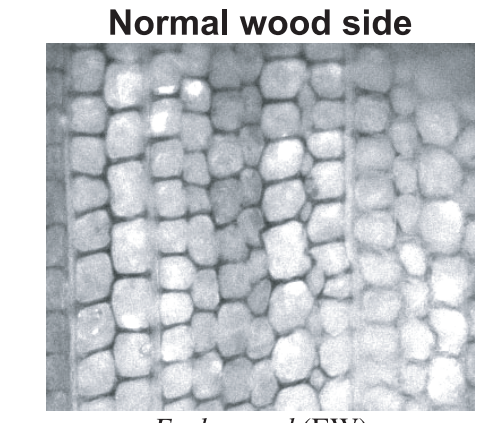

Early wood (EW)

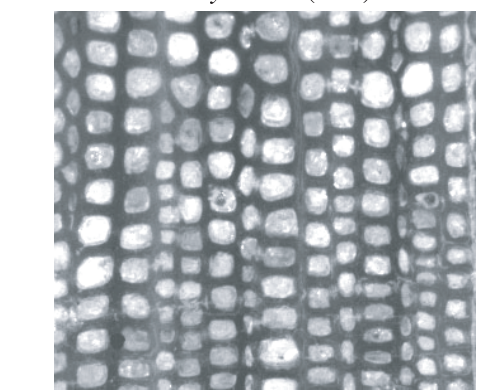

Late wood 1 (LW1)

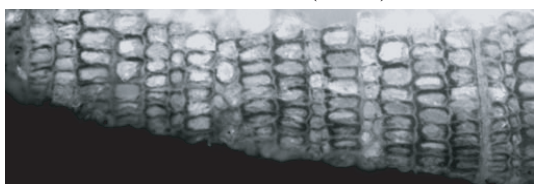

Late wood 2 (LW2)

Figure 8. The seven types of wood distinguished from shrinkage results on spruce.

level. The microscopic data collected in this work will allows us to investigate deeper in this direction.

\section{CONCLUSION}

A novel method is proposed to measure the free shrinkage of wood tissues in the transversal plane (radial and tangential). The experimental system involves use of an optical microscope with reflective light and two objectives with the same magnification, one working normally in air and the other immersed in water. In order to measure free shrinkage on very small zones, sub-units were separated from each other on a common base, using a diamond wire microsaw.

The images collected were processed using a vectorial image analysis tool developed by our team. Specific functions were implemented in this software for the purpose of the present study, and notably the extraction of shrinkage values from closed chains of points connecting the same specific anatomical references on both images.

Measurements were performed in two softwood species (spruce and Douglas fir), on both normal wood and reaction wood. Of the principal results obtained, reference should be made to the low shrinkage and high anisotropy of earlywood, the high, practically isotropic shrinkage of latewood, and the low shrinkage (with respect to cell wall thickness) and inversed anistropy of compression wood.

These data are valuable, firstly in order to validate explanatory approaches regarding the shrinkage of different types of cell patterns, and secondly to predict the shrinkage of a whole ring by change of scale. 


\section{REFERENCES}

[1] Badel E., Perré P., Using a digital X-ray imaging device to measure the swelling coefficients of a group of wood cells, NDT\&E International 34 (2001) 345-353

[2] Barkas W., Wood water relationships, VI. The influence of ray cells on the shrinkage of wood, Trans. Faraday Soc. 37 (1941) 535-547.

[3] Bosshard H.H., Holzkunde, Band 2 : Zur Biologie, Physik und Chemie des Holzes, Birkhäuser, Basel, 1984.

[4] Botosso P., Une méthode de mesure du retrait microscopique du bois : Application à la prédiction du retrait tangentiel d'éprouvettes de bois massif de sapin pectiné (Abies alba Mill.), Thèse, Université Nancy I, 1997.

[5] Boutelje J., The relationship of structure to transverse anisotropy in wood with reference to shrinkage and elasticity, Svensk papperstidning 65 (1962) 209-215.

[6] Boutelje J., On shrinkage and change in microscopic void volume during drying, as calculated from measurements on microtome cross sections of Swedish pine, Holzforshung 65 (1962) 209-215.

[7] Boutelje J., The relationship of structure to transverse anisotropy in wood with reference to shrinkage and elasticity, Svensk papperstidning 75 (1972) 1-6.

[8] Farruggia F., Perré P., Microscopic tensile tests in the transverse plane of earlywood and latewood parts of spruce, Wood Sci. Tech. 34 (2000) 65-82.

[9] Gibson L.J., Ashby M.F., Cellular solids: structure and properties, Pergamon Press, 1988.

[10] Ivkovica M., Rozenberg P., A method for describing and modelling of within-ring wood density distribution in clones of three coniferous species, Ann. For. Sci. 61 (2004) 759-769.

[11] Kawamura Y., Studies on the properties of rays III. Influence of rays on anisotropic shrinkage of wood, Mokuzai Gakkaishi, 30 (1984) 785-790.

[12] Kelsey K., A critical review of the relationship between the shrinkage and structure of wood, Division of Forest products technological paper No. 28, CSIRO, Melbourne, 1963.
[13] Kollmann F.P., Cote W.A., Principles of wood science and technology, Vol. 1, Solid wood, Springer-Verlag, 1968.

[14] Mariaux A., La section transversale de fibre observée avant et après séchage sur bois massif, Bois Forêts Trop. 221 (1989) 65-76.

[15] Mazet J.F., Nepveu G., Relations entre caractéristiques de retrait et densité du bois chez le pin sylvestre, le sapin pectiné et l'epicéa commun, Ann. Sci. For., 48 (1991) 87-100.

[16] Mikajiri N., Matsumura J., Okuma M., Observations by LV-SEM of shrinkage and anisotropy of tracheid cells with desorption, Mokuzai Gakkaishi, 47 (2001) 289-294.

[17] Park Y.I., Dallaire G., Morin H., A method for multiple intra-ring demarcation of coniferous trees, Ann. For. Sci. 63 (2006) 9-14.

[18] Perré P., MeshPore: a software able to apply image-based meshing techniques to anisotropic and heterogeneous porous media, Drying technology, 23 (2005) 1993-2006.

[19] Perré P., Wood as a multi-scale porous medium : Observation, experiment, and modelling, Proceedings of the First International conference of the European Society for wood mechanics, 2002, EPFL, Lausanne, Switzerland, pp. 365-384.

[20] Quirk J.T., Shrinkage and related propertied of Douglas-fir cell walls, Wood Fiber Sci. 16 (1982) 115-133.

[21] Roboty Onwondault, O., Détermination du retrait radial et tangentiel d'un groupe de cellules homogène par microscopie optique : validation de la méthode sur le chêne et application au Burkéa africana, DEA Sciences du bois, LERMaB, Nancy, 2002.

[22] Watanabe U., Norimoto M., Shrinkage and elasticity of normal and compression woods in conifers, Mokuzai Gakkaishi, 42 (1996) 651-658.

[23] Watanabe U., Fujita M., Norimoto M., Transverse shrinkage of coniferous wood cells examined using replica method and power spectrum analysis Holzforshung 52 (1998) 200-206.

[24] Watanabe U., Norimoto M., Fujita M., Gril J., Transverse shrinkage anisotropy of coniferous wood investigated by the power spectrum analysis, J. Wood Sci. 44 (1998) 9-14. 